\title{
PENGARUH MODEL PEMBELAJARAN STUDENT TEAMS ACHIEVEMENT DIVISION (STAD) TERHADAP KEMAMPUAN PEMAHAMAN KONSEP MATEMATIKA SISWA SMP SATU ATAP NEGERI 5 PANGURURAN TAHUN PELAJARAN 2018/2019
}

\author{
Regina Sabariah Sinaga ${ }^{1}$ Julia Eka Syahputri $^{2}$ \\ STKIP Budidaya Binjai \\ reginasabariah@gmail.com
}

\begin{abstract}
ABSTRAK
Tujuan dari penelitian ini adalah untuk mengetahui pengaruh model pembelajaran Student Teams Achievement Division (STAD) terhadap kemampuan pemahaman konsep matematika SMP Satu Atap Negeri 5 Panguruan Tahun Pelajaran 2018/2019. Penelitian ini merupakan penelitian eksperimen, dengan rancangan desain penelitian pretest and postest control group design. Instrument yang digunakan dalam penelitian ini adalah tes kemampuan pemahaman konsep matematika yang berbentuk uraian, dengan materi yang diajarkan adalah bentuk aljabar. Populasi dalam penelitian ini adalah seluruh siswa kelas VIII SMP Satu Atap Negeri 5 Panguruan, sedangkan sampel dalam penelitian ini terdiri dari dua kelas. Satu kelas sebagai kelompok eksperimen dan satu kelas lagi sebagai kelompok kontrol. Sampel pada kelompok eksperimen berjumlah 25 orang, dan sampel pada kelompok kontrol juga berjumlah 25 orang. Data dalam penelitian ini dianalisis dengan menggunakan uji regresi sederhana. Rata-rata tes kemampuan pemahaman konsep matematika kelas ekperimen sebelum dan sesudah pembelajaran adalah 68,2 dan 80. Sedangkan rata-rata tes kemampuan pemahaman konsep matematika kelas kontrol sebelum dan sesudah pembelajaran adalah 68,6 dan 70,6. Pengujian hipotesis dalam penelitian ini menggunakan uji-r. Sebelum uji-r dilakukan terlebih dahulu dilakukan uji pendahuluan yaitu uji keberartian dan uji linieritas. Setelah dilakukan perhitungan diperoleh hasil uji keberartian dengan nilai $F_{\text {hitung }}$ adalah 26,19 sedangkan nilai $F_{\text {tabel }}$ adalah 4,28. Selanjutnya dilakukan perhitungan uji linieritas dengan diperoleh nilai $F_{\text {hitung }}$ adalah 1,03 sedangkan nilai $F_{\text {tabel }}$ adalah 2,66. Setelah uji pendahuluan dilakukan selanjutnya dapat dilakukan perhitungan uji-r untuk mengetahui tingkat kemampuan pemahaman konsep matematika siswa sebelum dan sesudah diajar dengan menggunakan model pembelajaran Student Teams Achievement Division (STAD) setelah dilakukan perhitungan diperoleh nilai $r_{\text {hitung }}$ pada kemampuan pemahaman konsep matematika siswa kelas eksperimen adalah 0,721 sedangkan nilai $r_{\text {tabel }}$ adalah 0,361 . Dengan demikian dapat disimpulkan bahwa terdapat pengaruh model pembelajaran Student Teams Achievement Division (STAD) terhadap kemampuan pemahaman konsep matematika siswa SMP Satu Atap Negeri 5 Panguruan Tahun Pelajaran 2018/2019.
\end{abstract}

Kata Kunci : Model Pembelajaran Student Teams Achievement Division (STAD), Kemampuan Pemahaman Konsep Matematika 


\section{PENDAHULUAN}

\section{LATAR BELAKANG}

Pendidikan merupakan upaya

untuk meningkatkan kualitas setiap individu, secara langsung disiapkan untuk mengikuti laju perkembangan ilmu pengetahuan dan teknologi dalam upaya meningkatkan mutu pendidikan yang sejalan dengan proses belajar mengajar. Pendidikan merupakan hal yang penting bagi setiap manusia, karena dapat mengembangkan potensi dirinya untuk mencapai kesejahteraan hidup.

Seperti yang dikemukakan oleh Abdurrahman bahwa :

Matematika perlu diajarkan kepada siswa karena (1) selalu digunakan dalam segala segi kehidupan; (2) semua bidang studi memerlukan keterampilan matematika yang sesuai; (3) merupakan sarana komunikasi yang kuat, singkat, dan jelas; (4) dapat digunakan untuk menyajikan informasi dalam berbagai cara; (5) meningkatkan kemampuan berpikir logis, ketelitian, dan kesadaran keruangan; dan (6) memberikan kepuasan terhadap usaha memecahkan masalah yang menantang.

Berdasarkan penjelasan di atas jelas bahwa matematika memegang peranan yang sangat penting dalam pendidikan, sehingga matematika seharusnya dijadikan bidang studi yang difavoritkan siswa, akan tetapi kenyataannya matematika menjadi momok menakutkan bagi siswa dalam mempelajarinya, sehingga hasil belajar pun kurang maksimal.

Berdasarkan hasil analisis tes kemampuan pemahaman konsep yang diberikan jelas terlihat bahwa masih kurangnya kemampuan pemahaman konsep matematika siswa. Selain itu persepsi negatif tentang matematika masih dimiliki oleh para siswa. Banyak siswa yang kurang tertarik dengan mata pelajaran matematika serta masih banyak siswa yang menganggap matematika itu sebagai pelajaran yang sulit.

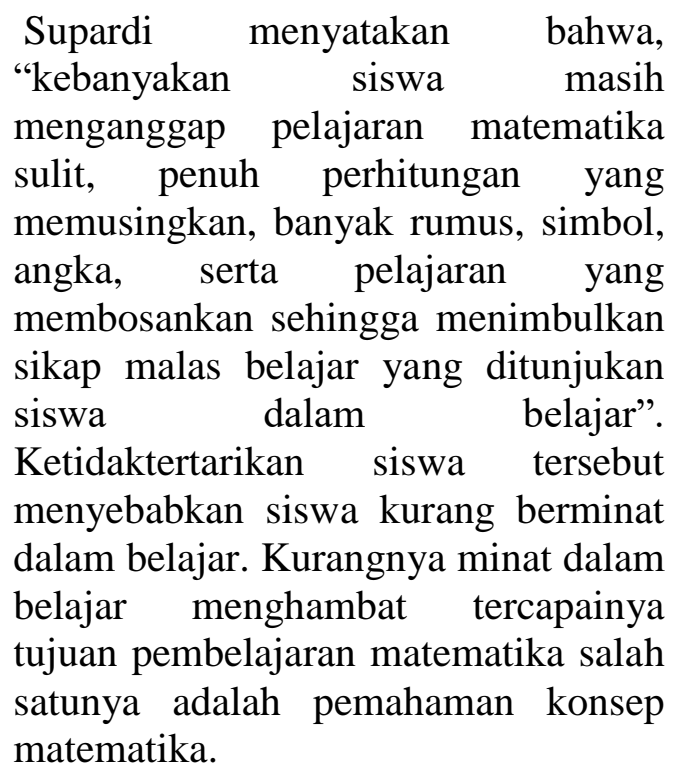

Kemampuan pemahaman konsep merupakan kemampuan siswa dalam memahami atau menguasai suatu materi atau objek dalam pembelajaran. Sanjaya (dalam 
Nuhyal Ulia) mengatakan bahwa pemahaman konsep adalah kemampuan siswa yang berupa penguasaan sejumlah materi pelajaran, dimana siswa tidak sekedar mengetahui sejumlah konsep yang dipelajari, tetapi mampu mengungkapan kembali dalam bentuk yang mudah dimengerti, dan mampu mengaplikasikan konsep yang sesuai dengan struktur kognitif yang dimilikinya. Adapun indiaktor indicator kemampuan pemahaman konsep matematika yang harus dicapai siswa berdasarkan Badan Standar Nasional Pendidikan (BSNP) tahun 2006 antara lain:

menyatakan ulang sebuah konsep (1), mengklasifikasikan objek menurut sifat-sifat tertentu (2), memberi contoh dan non contoh (3), menyajikan konsep dalam berbagai bentuk representasi matematis (4), mengembangkan syarat perlu atau syarat cukup suatu konsep (5), menggunakan prosedur atau operasi tertentu (6), mengaplikasikan konsep atau algoritma pemecahan masalah (7).

Mengatasi masalah-masalah dalam penguasaan konsep matematika, pendidik dapat menggunakan model-model pembelajaran yang dapat merangsang kemampuan siswa untuk belajar. Model adalah cara (pola) untuk mengajar. Sedangkan pembelajaran adalah membelajarkan siswa menggunakan asas pendidikan maupun teori belajar. Jadi model pembelajaran adalah suatu perencanaan atas suatu pola yang digunakan sebagai pedoman dalam merencanakan pembelajaran di kelas. Salah satu alternatif model pembelajaran yang dapat digunakan adalah model pembelajaran kooperatif. "Menurut Slavin (dalam Muhammad Firdaus) pembelajaran kooperatif merujuk pada berbagai macam metode pengajaran sehingga siswa bekerja dalam kelompok-kelompok kecil untuk saling membantu satu sama lainnya dalam mempelajari materi pembelajaran.

Salah satu model pembelajaran kooperatif adalah model pembelajaran kooperatif tipe Student Teams Achievement Division (STAD). “(Slavin, dalam Rayi Siti Fitriani) menjelaskan bahwa

Student Teams Achievement Division (STAD) merupakan salah satu model pembelajaran kooperatif yang paling sederhana dan merupakan model yang paling baik untuk permulaan bagi para guru yang baru menggunakan pendekatan kooperatif". Model pembelajaran Student Teams Achievement Division (STAD) merupakan model pembelajaran dimana siswa belajar dan bekerja sama dalam kelompok-kelompok kecil yang anggotanya terdiri dari 4 hingga 5 orang dengan struktur kelompok yang heterogen. 
Model pembelajaran Student Teams Achievement Division (STAD) membagi siswa dalam kelompok kecil yang heterogen dalam hal kemampuan akademis, jenis kelamin, dan sosial ekonomi yang melibatkan siswa untuk saling membantu dan mendukung dalam menyelesaikan tugas sehingga mempunyai banyak kesempatan untuk mengolah informasi, meningkatkan keterampilan berkomunikasi dan meningkatkan pemahaman konsep matematika siswa. Dengan begitu kesulitan pemahaman materi yang tidak dapat dipecahkan sendiri dapat dipecahkan secara bersama - sama dalam kelompoknya dengan bimbingan guru.

Berdasarkan uraian permasalahan diatas, maka peneliti termotivasi untuk melakukan penelitian tentang Pengaruh Model Pembelajaran Student Teams Achievement Division (STAD) terhadap kemampuan pemahaman konsep matematika siswa SMP Satu Atap Negeri 5 Pangururan tahun pelajaran 2018/2019.

\section{Tujuan Penenlitian}

Adapun yang menjadi tujuan penelitian ini adalah

1. Untuk mengetahui kemampuan pemahaman konsep matematika siswa yang di ajarkan dengan model pembelajaran Student Teams Achievement Divisions (STAD) lebih baik dibandingkan dengan siswa yang di ajarkan dengan model pembelajaran konvensional.

2. Untuk mengetahui model pembelajaran Student Teams Achievement Divisions (STAD) mempunyai pengaruh yang signifikan terhadap kemampuan pemahaman konsep matematika siswa

\section{METODE PENELITIAN}

Jenis penelitian ini adalah penelitian eksperimen semu. Populasi dalam penelitian ini adalah seluruh siswa kelas VIII SMP Satu Atap Negeri 5 Pangururan Tahun Pelajaran 2018/2019 sebanyak 2 kelas. Sampel dalam penelitian ini diambil dengan cara sampling jenuh, yaitu seluruh anggota populasi dijadikan sampel. Adapun sampel dalam penelitian ini adalah kelas VIII-B sebanyak 25 orang sebagai kelas Eksperimen dan kelas VIII-A sebanyak 25 orang sebagai kelas kontrol.

Desain yang digunakan dalam penelitian ini adalah pretest and post-test control group desaign. Adapun pola dalam desain ini adalah 
Jurnal Serunai Ilmu Pendidikan

Vol.6, No.1, Juni 2020

e-ISSN $2621-2676$

p-ISSN 2528 - 0775

\begin{tabular}{|c|c|c|c|}
\hline $\mathrm{E}$ & $0_{1}$ & $X$ & $0_{2}$ \\
\hline $\mathrm{K}$ & $0_{1}$ & & $0_{2}$ \\
\hline
\end{tabular}

E : kelompok eksperimen

$\mathrm{K}$ : kelompok kontrol

X : model pembelajaran Student Teams

Achievement Divisions (STAD)

Teknik pengumpulan data dalam penelitian ini menggunakan observasi dan tes kemampuan pemahaman konsep matematika siswa. Tes yang digunakan terbagi menjadi dua, yaitu tes awal (pretest) untuk mengetahui kemampuan pemahaman konsep matematika siswa sebelum proses pembelajaran dan tes akhir (post-test) untuk mengetahui kemampuan pemahaman konsep matematika siswa setelah dilakukan proses pembelajaran.

\section{HASIL DAN PEMBAHASAN HASIL}

Proses pembelajaran dilakukan pada kedua kelas. Kelas eksperimen menggunakan model pembelajaran Student Teams Achievement Division (STAD) dan Lembar Aktivitas Siswa (LAS), sedangkan pada kelas kontrol, proses pembelajaran menggunakan pembelajaran konvensional. Hasil penelitian ini diambil dari nilai pretest dan nilai post-test kemampuan pemahaman konsep matematika siswa. Nilai rata-rata pretest siswa kelas eksperimen adalah 68,2 dan nilai rata-rata pretest siswa kelas kontrol adalah 68,6. Sedangkan nilai rata-rata posttest siswa kelas eksperimen adalah 80 dan nilai rata-rata post-test sisw kelas kontrol adalah 70,6 .

Dengan demikian dapat dilihat bahwa terdapat peningkatan yang signifikan pada kelas eksperimen antara sebelum dan sesudah proses pembelajaran.

Berdasarkan hasil pretest dan posttest yang telah dikerjakan, maka dilakukan perhitungan dengan menggunakan uji analisis regresi sederhana. Uji ini dilakukan untuk melihat seberapa besar pengaruh model pembelajaran Student Teams Achievement Divisions (STAD) terhadap kemampuan pemahaman konsep matematika siswa. Hasil analisis regresi yang telah dilakukan adalah seperti tampak pada tabel berikut ini : 
Tabel 1. Hasil Analisis Varians Untuk

Regresi Linier

$\widehat{\mathbf{Y}}=18,90+0,90 \mathrm{X}$

\begin{tabular}{|c|c|c|c|c|}
\hline $\begin{array}{l}\text { Sumber } \\
\text { Varians }\end{array}$ & Dk & JK & KT & $\mathbf{F}$ \\
\hline Total & 25 & 163550 & & \\
\hline $\begin{array}{l}\text { Koefisien } \\
\text { (a) }\end{array}$ & 1 & 160000 & 160000 & \\
\hline $\begin{array}{l}\text { Regresi } \\
\text { (b丁a) }\end{array}$ & $\begin{array}{c}1 \\
23\end{array}$ & $\begin{array}{l}1890 \\
1660\end{array}$ & $\begin{array}{c}1890 \\
72,17\end{array}$ & 26,19 \\
\hline Sisa $(\mathrm{S})$ & & & & \\
\hline $\begin{array}{l}\text { Tuna } \\
\text { Cocok } \\
\text { (TC) }\end{array}$ & 6 & 842,46 & 140,41 & 1,03 \\
\hline
\end{tabular}

Setelah analisis varians untuk regresi diketahui, selanjutnya dilakukan uji keberartian. Uji ini dilakukan untuk mengetahui apakah hubungan variabel bebas dengan variabel terikat berarti signifikan atau tidak. Hasil dari uji keberartian adalah sebagai berikut :

Tabel 2. Hasil Uji Keberartian

\begin{tabular}{|c|c|c|c|l|}
\hline $\mathbf{F}_{\text {hitung }}$ & $\begin{array}{l}\mathbf{F}_{\text {tabel }} \\
\boldsymbol{\alpha =} \\
\mathbf{5 \%}\end{array}$ & $\begin{array}{c}\mathbf{d k} \\
\text { pemb } \\
\text { ilang }\end{array}$ & $\begin{array}{c}\text { dk } \\
\text { penye } \\
\text { but }\end{array}$ & $\begin{array}{l}\text { Keterang } \\
\text { an }\end{array}$ \\
\hline 26,19 & 4,28 & 1 & 23 & $\begin{array}{l}\text { Koefisien } \\
\text { arah } \\
\text { regresi } \\
\text { berarti } \\
(\mathrm{b} \neq 0)\end{array}$ \\
\hline
\end{tabular}

$\mathrm{F}_{\text {hitung }}>\mathrm{F}_{\text {tabel }}$ berarti Ho ditolak dan Ha diterima, dengan demikian dapat disimpulkan bahwa koefisien arah regresi berarti $(b \neq 0)$.

Setelah koefisien arah regresi berarti maka selanjutnya dilakukan uji linieritas, dengan tujuan untuk mengetahui apakah dua variabel mempunyai hubungan yang linear atau tidak secara signifikan. Hasil uji linieritas adalah :

Tabel 3. Hasil Uji Linieritas

\begin{tabular}{|c|c|c|c|l|}
\hline $\mathbf{F}_{\text {hitung }}$ & $\begin{array}{c}\mathbf{F}_{\text {tabel }} \\
\mathbf{\alpha =} \\
\mathbf{5 \%}\end{array}$ & $\begin{array}{c}\mathbf{d k} \\
\text { pembi } \\
\text { lang }\end{array}$ & $\begin{array}{c}\text { dk } \\
\text { penye } \\
\text { but }\end{array}$ & $\begin{array}{l}\text { Keteran } \\
\text { gan }\end{array}$ \\
\hline 1,03 & 2,66 & 6 & 18 & $\begin{array}{l}\text { Regresi } \\
\text { linier }\end{array}$ \\
\hline
\end{tabular}

Hasil dari perhitungan tersebut diperoleh nilai $=1,03$, sedangkan harga $F_{\text {tabel }}(6,18)=2,66$ untuk taraf signifikan $5 \%$. Dengan demikian harga $F_{\text {hitung }}<$ $F_{\text {tabel }}$ berarti Ho diterima dan Ha ditolak, dengan demikian kesimpulannya adalah regresi linier.

Setelah data yang diketahui berarti dan linier, selanjutnya dilakukan pengujian terhadap hipotesis. Perhitungan uji hipotesis I untuk mengetahui apkah kemampuan pemahaman konsep matematika siswa yang diajar dengan model pembelajaran Student Teams Achievement Division (STAD) lebih 
baik dibandingkan dengan model pembelajaran konvensional. Adapun kriteria penerimaan $\mathrm{Ha}$ adalah apabila nilai rata-rata post-test dari kelas eksperimen lebih baik dibandingkan nilai rata-rata posttest dari kelas kontrol. Hasil perhitungan nilai rata rata pretest dan post-test dari kelas eksperimen dan kelas kontrol dapat dilihat pada tabel berikut:

\section{Tabel 4. Hasil Uji Hipotesis I}

\begin{tabular}{|c|c|c|c|}
\hline Kelas & Pre test & Post-test & N \\
\hline Eksperimen & 68,2 & 80 & 25 \\
\hline Kontrol & 68,6 & 70,6 & 25 \\
& & & \\
\hline
\end{tabular}

Berdasarkan hasil perhitungan nilai pretest dan post-test siswa pada kelas eksperimen dan kontrol, jelas terlihat bahwa setelah dilakukan pembelajaran dengan model pembelajaran Student Teams Achievement Division (STAD), nilai ratarata siswa dikelas eksperimen lebih tinggi dari nilai rata-rata siswa dikelas kontrol. Karena nilai rata-rata siswa dikelas eksperimen lebih tinggi dari nilai rata-rata siswa dikelas kontrol $(80>70,6)$, maka Ho ditolak dan Ha diterima,

Perhitungan uji hipotesis II dilakukan untuk mengetahui apakah terdapat pengaruh yang signifikan dalam pembelajaran dengan menggunakan model pembelajaran Student Teams Achievement Divisions (STAD) terhadap kemampuan pemahaman konsep matematika siswa. Pengujian hipotesis dalam penelitian ini menggunakan uji-r dengan menggunakan data hasil kemampuan pemahaman konsep matematika yang diperoleh siswa, Hasil perhitungan dapat dilihat pada tabel berikut:

Tabel 5. Hasil Uji Hipotesis II

\begin{tabular}{|c|c|c|l|}
\hline $\mathbf{r}_{\text {hitung }}$ & $\begin{array}{c}\mathbf{r}_{\text {tabel }} \\
\boldsymbol{\alpha}= \\
\mathbf{5 \%}\end{array}$ & $\mathbf{N}$ & \multicolumn{1}{|c|}{ Keterangan } \\
\hline 0,721 & 0,396 & 25 & $\begin{array}{l}\text { Terdapat pengaruh } \\
\text { yang signifikan dari } \\
\text { model pembelajaran } \\
\text { Student Teams } \\
\text { Achievement } \\
\text { Divisions (STAD) } \\
\text { terhadap } \\
\text { kemampuan } \\
\text { pemahaman konsep } \\
\text { matematika siswa. }\end{array}$ \\
\hline & & & \\
\hline
\end{tabular}

Setelah perhitungan dengan menggunakan uji-r dilakukan, maka diperoleh nilai $r_{\text {hitung }}=0,721$. Kemudian nilai tersebut dibandingkan dengan nilai $r_{\text {tabel }}$ dengan $\mathrm{n}=25$ dan taraf signifikan $5 \%$ $=0,396$. Karena harga $r_{\text {hitung }}>r_{\text {tabel }}$ maka 
Ho ditolak dan $\mathrm{Ha}$ diterima, dengan demikian dapat disimpulkan terdapat pengaruh yang signifikan dari model pembelajaran Student Teams Achievement Divisions (STAD) terhadap kemampuan pemahaman konsep matematika siswa.

\section{PEMBAHASAN}

Proses pembelajaran dengan menggunakan model pembelajaran Student Teams Achievement Division (STAD) menjadikan siswa lebih mampu berpartisipasi dalam pembelajaran,siswa menjadi lebih aktif, siswa menjadi lebih bertanggung jawab terhadap kelompoknya, siswa menjadi lebih tahu inti dari pembelajaran yang mereka lakukan dengan adanya kesimpulan, siswa menjadi lebih mampu memahami konsep-konsep dari materi yang diberikan, serta kesan senang dalam pembelajaran lebih terlihat. Sedangkan pembelajaran dengan menggunakan model pembelajaran konvensional menjadikan siswa kurang aktif, banyak siswa yang menunjukkan sikap bosan karena harus mengerjakan soal-soal sendiri, terlebih lagi bagi siswa yang memiliki kemampuan rendah. Meskipun dalam pelaksanaan pembelajaran siswa juga telah diberi waktu untuk aktif dalam bertanya, akan tetapi hasilnya pembelajaran tetaplah kurang aktif. Hal ini dapat dilihat dari hasil nilai siswa pada kelas eksperimen dan kelas kontrol.

Uji regresi yang dilakukan terhadap hasil pretest dan post-test pada kelas eksperimen menunjukkan adanya perbedaan hasil yang cukup signifikan antara sebelum dan sesudah diberikan perlakuan. Setelah dilakukan perhitungan diperoleh hasil nilai $r_{\text {hitung }}=0,721$ sedangkan nilai $r_{\text {tabel }}=$ 0,396. Karena $\mathbf{r}_{\text {hitung }}>\mathbf{r}_{\text {tabel }}$ maka Ho ditolak dan Ha diterima. Berdasarkan tabel interpretasi koefisien korelasi dengan nilai $r_{x y}=0,721$ menunjukkan nilai tersebut berada pada level tinggi.

Jelas terlihat bahwa kemampuan pemahaman konsep matematika siswa sesudah diberikan perlakuan lebih baik daripada sebelum diberikan perlakuan. Dengan demikian dapat ditarik kesimpulan bahwa terdapat pengaruh yang signifikan dari model pembelajaran Student Teams Achievement Division (STAD) terhadap kemampuan pemahaman konsep matematika siswa. 


\section{KESIMPULAN DAN SARAN}

\section{Kesimpulan}

Setelah dilaksanakannya penelitian serta berdasarkan analisis data dan pengujian hipotesis yang dilakukan maka dapat diambil kesimpulan sebagai berikut:

1. Kemampuan pemahaman konsep matematika siswa yang belajar dengan model pembelajaran Student Teams Achievement Division (STAD) lebih baik dibandingkan siswa yang diajar dengan model pembelajaran konvensional. Hal ini dapat dilihat dari hasil perhitungan nilai rata-rata $(\bar{X})$ posttest pada kelas kontrol yaitu: 70,6 , sedangkan nilai rata-rata $(\bar{X})$ posttest pada kelas eksperimen yaitu: 80 .

2. Terdapat pengaruh yang signifikan dari penggunaan model pembelajaran Student Teams Achievement Division (STAD) terhadap kemampuan pemahaman konsep matematika siswa. Hal ini dapat dilihat dari hasil perhitungan uji regresi dengan diperoleh nilai koefisien korelasi ( $\left.\mathrm{r}_{\text {hitung }}\right)=0,721$. Kisaran nilai $r_{\text {hitung }}=0,721$ sesuai dengan tabel interpretasi koefisien korelasi berada pada level tinggi. 
Jurnal Serunai Ilmu Pendidikan

Vol.6, No.1, Juni 2020

e-ISSN 2621 - 2676

p-ISSN 2528 - 0775

Saran

Dengan memperhatikan hasil penelitian dan pembahasan, peneliti memberikan saran sebagai berikut:

1. Bagi siswa, diharapkan siswa secara aktif dalam membangun pengetahuan, meningkatkan kemampuan penalaran matematikanya serta memperoleh pengalaman baru dan belajar lebih bermakna.

2. Bagi guru, dapat menjadi salah satu acuan dalam penggunaan model pembelajaran yang bervariasi dalam mengejar dikelas.

3. Bagi peneliti, produk ini dapat dijadikan sebagai bahan masukan dan bandingan dalam pengembangan penelitian selanjutnya terkait penerapan paradigma baru pembelajaran disekolah.

4. Bagi sekolah, memberikan masukan dan pertimbangan untuk meningkatkan kualitas pembelajaran di sekolah khususnya dalam pemilihan model pembelajaran.

5. Bagi lembaga pendidikan, memberikan saran bagi pemerintah dalam upaya meningkatkan kualitas pendidikan melalui model pembelajaran tertentu dalam proses belajar mengajar.

\section{DAFTAR PUSTAKA}

Abdurrahman. Hakikat Belajar Matematika. Jakarta: Rineka Cipta, 2009

Arikunto, Suharsimi. Dasar-Dasar Evaluasi Pendidikan. Jakarta : PT. Bumi Aksara, 2012

Fitriani, Rayi Siti. "Pengaruh Pembelajaran Kooperatif Tipe STAD Terhadap Kemampuan Pemahaman dan Komunikasi Matematis Siswa Sekolah Dasar". Jurnal Pendidikan Guru Sekolah Dasar. Vol. 1. No.1. 2015. ISSN : 2477-5673

Firdaus, Muhammad. " Pengaruh Model Pembelajaran Kooperatif Tipe Student Teams Achievement Division (STAD) Terhadap Hasil Belajar Siswa SMP”. Jurnal Pendidikan Informatika dan Sains. Vol. 5. No. 1. 2016

Sugiyono. Statistik Untuk Penelitian. Bandung : Alfabeta, 2012

Ulia, Nuhyal. "Peningkatan Pemahaman Konsep Matematika Materi Bangun datar Dengan Pembelajaran Kooperatif Tipe Group Investigation Dengan Pendekatan Saintifik Di SD". Jurnal Tunas Bangsa. ISSN 2355-0066 